\title{
DAMPAK KUALITAS HUBUNGAN ANTAR MANUSIA (HUMAN RELATION) TERHADAP KINERJA SUMBER DAYA MANUSIA ORGANISASI
}

\author{
Dhian Rosalina ${ }^{1 \% *}$, Devi Apiska ${ }^{2)}$ \\ 1) Fakultas Ekonomi, Universitas Samudra \\ Email: dhian.rosalina@unsam.ac.id \\ 2) Fakultas Ekonomi, Universitas Samudra \\ Email: devipiska@gmail.com
}

\begin{abstract}
Abstrak
Penelitian ini dilakukan pada PT Timbang Langsa, Aceh bertujuan untuk mengetahui pengaruh bagaimana dampak human relation terhadap kinerja sumber daya manusia dalam organisasi. Populasi dalam penelitian ini adalah keseluruhan karyawan tetap PT Timbang Langsa, dan karyawan yang menjadi responden adalah sebanyak 134 responden. Teknik sampling yang digunakan adalah purposive sampling dengan beberapa kriteria tertentu.. Metode analisis data yang digunakan adalah analisis regresi linier berganda. Hasil dari penelitian ini adalah Human relation berpengaruh positif dan signifikan terhadap kinerja karyawan pada PT Perkebunan Timbang Langsa dengan hasil uji t yaitu nilai thitung $>$ ttabel $(5,573>1,656)$ dan nilai $t$ sig yaitu $0,000<0,05$. Nilai koefisien determinasi (R2) yaitu 0,19 0atau 19,0\%. Hal ini menunjukkan variabel human relation mempengaruhi kinerja karyawan pada PT. Perkebunan Timbang Langsa sebesar 19,0\%, dan sisanya 81,0\% dipengaruhi oleh variabel lain yang tidak diteliti dalam penelitian ini.
\end{abstract}

Keywords: human relation, kinerja Sumber Daya Manusia 


\section{PENDAHULUAN}

Sumber daya manusia adalah aset yang mempunyai peran penting dalam kemajuan sebuah perusahaan. Hal ini dikarenakan sumber daya manusia berperan menjalankan roda kehidupan organisasi. Dalam mencapai tujuan, setiap organisasi dituntut untuk selalu mampu bertahan dan berkembang, dengan sumberdaya manusia sebagai ujung tombaknya.

Salah satu hal terpenting yang berkaitan dengan permasalahan SDM adalah permasalahan kinerja. Kinerja adalah hasil kerja secara kualitas dan kuantitas yang dicapai seorang karyawan dalam melaksanakan tugas yang dibebankan kepadanya. Kinerja karyawan yang berkualitas dapat berdampak positif bagi keberlangsungan hidup sebuah perusahaan (Rivai dan Basri, 2012:14). Selain itu, baik tidaknya suatu kinerja dapat menjadi tolak ukur untuk melakukan pengambilan keputusan yang efektif dan efisien bagi perusahaan. Namun demikian, tidak semua karyawan memiliki kinerja yang berkualitas. Hal ini dikarenakan banyak berbagai faktor yang mempengaruhi kinerja dari setiap karyawan, salah satunya yaitu human relation (hubungan antar manusia).

Human relation (hubungan antar manusia) adalah suatu hubungan kemanusiaan yang harmonis, tercipta atas kesadaran dan kesediaan melebur keinginan individu demi terpadunya keinginan bersama (Hasibuan, 2009:137). Dalam organisasi, karyawan dituntut untuk memiliki hubungan kemanusiaan yang baik, yang diantaranya adalah hubungan terhadap pimpinan, bawahan, maupun rekan kolega.. Human relation (hubungan antar manusia) merupakan hal yang penting dalam meningkatkan kinerja karena berkaitan dengan komunikasi yang meliputi pikiran, perasaan dan kerja sama dalam melakukan pekerjaan. Hal ini dilakukan untuk menciptakan hubungan kerja yang harmonis sehingga karyawan akan merasa nyaman dan
NIAGAWAN Vol 7 No 2 Juli 2018

fokus dalam melaksanakan tugas dan berdampak positif terhadap kinerja karyawan.

PT. Perkebunan Timbang Langsa merupakan salah satu perusahaan perkebunan yang mengelola komuditas kelapa sawit. Produk yang dihasilkan pada PT. Perkebunan Timbang Langsa yaitu tandan buah segar kelapa sawit yang selanjutnya diolah dan dipasarakan ke provinsi Sumatera Utara. Perusahaan mengalami masalah yang berhubungan dengan hubungan antar sumberdaya manusia, hal ini terungkap dari survei yang dilakukan oleh Apiska (2018) yang menemukan bahwa

Berdasarkan observasi awal pada tanggal 6 januari 2018 terhadap 20 orang karyawan tetap PT. Perkebunan Timbang Langsa yang berkaitan dengan human relation (hubungan antar manusia) dan kinerja diperoleh sebanyak $40 \%$ karyawan mengeluhkan sulit meningkatkan kinerja karena suasana kerja secara sosial tidak mendukung, seperti persaingan antara kolega, komunikasi yang buruk dengan pimpinan maupun bawahan.. Sedangkan $30 \%$ menyatakan bahwa memiliki hubungan yang baik antara sesama karyawan maupun dengan atasan menyebabkan bekerja dengan tenang dan fokus tanpa ada masalah yang menghambat pekerjaan sehingga kinerja meningkat. Sedangkan $30 \%$ responden yang lain menyatakan bahwa kinerja lebih banyak terganggu oleh masalah ketidakmampuan mengendalikan diri, tidak mampu memisahkan urusan pribadi dengan pekerjaan..

\section{TINJAUAN PUSTAKA}

\section{Human Relation}

Effendy (2009:50) menyatakan

human relation merupakan komunikasi persuasif yang dilakukan oleh seseorang kepada orang lain secara tatap muka dalam situasi kerja dan dalam organisasi dengan tujuan untuk meningkatkan semangat dalam bekerja dan bekerjasama agar dapat mencapai hasil yang memuaskan. Human relation menurut Hasibuan (2009: 137) adalah 
NIAGAWAN Vol 7 No 2 Juli 2018

hubungan kemanusiaanyang harmonis, tercipta atas kesadaran dan kesediaan melebur keinginan individu demi terpadunya keinginan bersama. Menurut Davis (2009:59) hubungan antar manusia adalah interaksi antara seseorang dengan orang lain baik dalam situasi tentang kerja atau dalam organisasi kekaryaan. Menurut Djaja (2011:142), manfaat dari Human Relation yaitu :

1. Mencegah salah pengertian antara pimpinan dan bawahan

2. Mengembangkan kerja sama antara pimpinan dan bawahan.

3. Dapat membentuk suatu teamwork yang efektif.

4. Mengerahkan individu dalam kelompok pada suatu tujuan.

Sedangkan menurut Effendi (2009:71), Human Relation yang baik sangat dibutuhkan dalam usaha mencapai tujuan yang telah ditetapkan perusahaan menerapkan prinsip-prinsip human relation dengan baik. Dalam kegiatan human relation seorang pemimpin perusahaan berusaha memecahkan masalah-masalah yang menimpa bawahannya secara individual. Tujuannya untuk menggugah kegairahan dan kegiatan bekerja dengan semangat kerjasama yang produktif dengan perasaan bahagia dan hati yang puas, baik kepuasan ekonomis, psikologis maupun kepuasan sosial. Human Relation mempunyai fungsi untuk memotivasi para karyawan, membangkitkan motif mereka, menggugah daya gerak mereka untuk bekerja lebih giat.

\section{Kinerja}

Menurut Bangun (2012:231), Kinerja adalah hasil pekerjaan yang dicapai karyawan berdasarkan persyaratan-persyaratan pekerjaan. Sedangkan menurut Umar (2009:164) , secara umum kinerja mengandung arti sebagai perbandingan antara hasil yang dicapai (output) dengan keseluruhan sumber daya yang digunakan (input). Selanjutnya Wibowo (2012:209) menyatakan kinerja merupakan prilaku nyata yang ditampilkan setiap orang sebagai prestasi kerja yang dihasilkan oleh karyawan sesuai dengan perannya dalam perusahaan. Selanjutnya Rivai dan Basri (2012:14) menyatakan kinerja merupakan hasil yang telah dicapai dari yang telah dilakukan, dikerjakan seseorang dalam melaksanakan kerja atau tugas. Kinerja adalah hasil dari seseorang secara keseluruhan selama periode tertentu di dalam melaksanakan tugas, seperti standar hasil kerja, target atau sasaran atau kriteria yang telah ditentukan terlebih dahulu dan telah disepakati bersama

Menurut Mangkunegara (2011:127), karakteristik orang yang mempunyai kinerja tinggi adalah sebagai berikut:

1. Memiliki tanggung jawab pribadi yang tinggi.

2. Berani mengambil dan menanggung resiko yang dihadapi.

3. Memiliki tujuan yang realistis.

4. Memiliki rencana kerja yang menyeluruh dan berjuang untuk merealisasi tujuannya.

5. Memanfaatkan umpan balik (feed back) yang konkrit dalam seluruh kegiatan kerja yang dilakukannya.

6. Mencari kesempatan untuk merealisasikan rencana yang telah diprogramkan

7. Hubungan Human Relation terhadap Kinerja

Human relation mempunyai hubungan yang positif terhadap kinerja. Hal ini sesuai dengan pendapat yang disampaikan oleh Munasef (2008:122), yang menyatakan human relation sebagai bentuk hubungan formal maupun informal yang dijalankan oleh pimpinan terhadap bawahan, oleh bawahan terhadap sesama bawahan dalam usaha memupuk kerjasama yang intim dan selaras guna mencapai tujuan yang ditetapkan. Dengan hubungan kerja yang harmonis, maka karyawan akan merasa nyaman dalam menyelesaikan tugas dan berdampak positif terhadap kinerja.

Sedangkan Effendy menyatakan human relation sangat dibutuhkan 
dalam mencapai tujuan organisasi. Dengan adanya human relation, dapat menggugah kegairahan dan berkerja dengan semangat dengan perasaan yang bahagia dan hati yang puas, baik kepuasan ekonomis, psikologis maupun kepuasan sosial. Human relation mempunyai fungsi untuk memotivasi karyawan, membangkitkan motif mereka, dan menggugah daya gerak mereka untuk dapat bekerja lebih giat dan dapat meningkatkan kinerja dan produktivitas kerjanya. Selanjutnya penelitian yang dilakukan oleh Kuswandi, Febriyanti dan Cahyono (2014) diperoleh hasil human relation berpengaruh positif terhadap kinerja pegawai. Kemudian penelitian yang dilakukan oleh Susanti, Musadieq dan Ruhana (2014) serta penelitian yang dilakukan oleh Talumantak, Kojo dan Dotulang (2016) diperoleh hasil bahwa human relation berpengaruh positif dan signifikan terhadap kinerja karyawan..

\section{METODE PENELITIAN}

\section{Teknik Pengumpulan Data}

Teknik pengumpulan data dalam penelitian ini adalah dengan observasi, wawancara, dan kuesioner. Kuesioner disusun dengan menggunakan skala Likert 1-5 dengan skor

$$
\begin{aligned}
& 1 \text { = sangat tidak setuju } \\
& 2=\text { tidak setuju } \\
& 3=\text { ragu ragu } \\
& 4=\text { setuju } \\
& 5=\text { sangat setuju }
\end{aligned}
$$

\section{Populasi dan Sampel}

Populasi dalam penelitian ini adalah seluruh karyawan tetap PT. Perkebunan Timbang Langsa yang berjumlah 202 responden.

Jumlah populasi ini terlalu besar, oleh karenanya penentuan jumlah sampel dalam penelitian ini menggunakan rumus Slovin yang dikemukakan oleh Sugiyono (2011:161), sebagai berikut :

$$
\mathrm{N}=\frac{\mathrm{N}}{1+\mathrm{N}\left(\mathrm{e}^{2}\right)}
$$

$\mathrm{n}=$ ukuran sampel

$\mathrm{N}=$ ukuran populasi

$\mathrm{e}=$ persen kesalahan karena kesalahan pengambilan sampel

Berdasarkan rumus Slovin di atas, untuk populasi sebesar 202 responden dan batas kesalahan yang diinginkan 5\% maka jumlah sampelnya adalah:

$$
\begin{aligned}
& \mathrm{n}=\frac{202}{1+202\left(0,05^{2}\right)} \\
& \mathrm{n}=\frac{202}{1,505} \\
& \text { 134,21 (dibulatkan menjadi } 134 \\
& \text { nden) }
\end{aligned}
$$

Dengan demikian, jumlah sampel dalam penelitian ini adalah sebanyak 134 responden. Teknik pengambilan sampel pada penelitian ini menggunakan Purposive Sampling dengan kriteria sebagai berikut :

a. Responden berstatus karyawan tetap

b. Pendidikan minimal adalah SMA

c. Usia minimal 30 tahun

d. Lama bekerja minimal satu tahun

\section{HASIL DAN PEMBAHASAN \\ Teknik Analisis}

\section{a. Statistik Deskriptif}

Statistik deskriptif digunakan untuk mengamati tanggapan responden mengenai variabel human relatiom yang dapat dilihat pada tabel 1 berikut ini: 
Tabel 1

Tanggapan Responden Pada Variabel Human Relation

\begin{tabular}{|c|c|c|c|c|c|c|c|c|c|c|}
\hline \multirow{2}{*}{ No } & \multicolumn{8}{|c|}{ Tanggapan Responden } \\
\cline { 2 - 13 } & \multicolumn{2}{|c|}{ SS } & \multicolumn{2}{|c|}{ S } & \multicolumn{2}{c|}{ KS } & \multicolumn{2}{c|}{ TS } & \multicolumn{2}{c|}{ STS } \\
\cline { 2 - 12 } & $\mathrm{F}$ & $\%$ & $\mathrm{~F}$ & $\%$ & $\mathrm{~F}$ & $\%$ & $\mathrm{~F}$ & $\%$ & $\mathrm{~F}$ & $\%$ \\
\hline 1 & 38 & 28,4 & 75 & 56,0 & 18 & 13,4 & 3 & 2,2 & 0 & 0,0 \\
\hline 2 & 31 & 23,1 & 86 & 64,2 & 16 & 11,9 & 1 & 0,7 & 0 & 0,0 \\
\hline 3 & 56 & 41,8 & 56 & 41,8 & 22 & 16,4 & 0 & 0,0 & 0 & 0,0 \\
\hline 4 & 57 & 42,5 & 62 & 46,3 & 14 & 10,4 & 1 & 0,7 & 0 & 0,0 \\
\hline 5 & 45 & 33,6 & 49 & 36,6 & 30 & 22,4 & 10 & 7,5 & 0 & 0,0 \\
\hline 6 & 42 & 31,3 & 77 & 57,5 & 14 & 10,4 & 1 & 0,7 & 0 & 0,0 \\
\hline 7 & 47 & 35,1 & 80 & 59,7 & 7 & 5,2 & 0 & 0,0 & 0 & 0,0 \\
\hline 8 & 20 & 14,9 & 100 & 74.6 & 14 & 10,4 & 0 & 0,0 & 0 & 0,0 \\
\hline
\end{tabular}

Sumber: Hasil Penelitian, diolah (2018)

a. Pada pernyataan pertama "Setiap karyawan menerapkan prinsip kerjasama yang tinggi dalam pekerjaannya", diperoleh tanggapan sangat setuju sebnayak 38 orang $(28,4 \%)$. Selanjutnya tanggapan setuju sebesar 75 orang $(56,0 \%)$, tanggapan kurang setuju sebesar 18 orang $(13,4 \%)$ dan tanggapan tidak setuju sebanyak 3 orang (2,2\%). Dengan demikian mayoritas responden dalam penelitian ini menyatakan setuju bahwa setiap karyawan menerapkan prinsip kerjasama yang tinggi dalam pekerjaannya.

b. Pada Pernyataan kedua "Setiap karyawan memiliki hubungan kerja yang baik dalam tim." mendapatkan tanggapan responden sangat setuju sebanyak 31 orang $(23,1 \%)$ serta tanggapan setuju sebanyak 86 orang $(64,2 \%)$. Selanjutnya tanggapan kurang setuju sebanyak 16 orang $(11,9 \%)$ dan tanggapan tidak setuju sebanyak 1 orang $(0,7 \%)$. Dengan demikian mayoritas responden dalam penelitian ini menyatakan setuju bahwa Setiap karyawan memiliki hubungan kerja yang baik dalam tim.

c. Pada Pernyataan ketiga "Setiap karyawan siap menghadapi permasalahan dalam pekerjannya" mendapatkan tanggapan responden sangat setuju sebanyak 56 orang $(41,8 \%)$, tanggapan setuju sebanyak 56 orang $(41,8 \%)$ dan tanggapan kurang setuju sebanyak 22 orang $(16,4 \%)$. Dengan demikian mayoritas responden dalam penelitian ini menyatakan setuju bahwa Setiap karyawan siap menghadapi permasalahan dalam pekerjannya.

d. Pada pernyataan keempat "Setiap karyawan memiliki mental yang kuat dalam setiap permasalahan.” mendapatkan tanggapan responden sangat setuju sebanyak 57 orang $(42,5 \%)$ serta tanggapan setuju sebanyak 62 orang (46,3\%). Sedangkan tanggapan kurang setuju sebanyak 14 orang $(10,4 \%)$ dan tanggapan tidak setuju sebanyak 1 orang $(0,7 \%)$. Dengan demikian mayoritas responden dalam penelitian ini menyatakan setuju bahwa Setiap 
karyawan memiliki mental yang kuat dalam setiap permasalahan.

e. Pada Pernyataan kelima "Setiap karyawan mampu mengendalikan emosi dalam melaksanakan pekerjaannya agar tercipta suasana yang kondusif." mendapatkan tanggapan responden sangat setuju sebanyak 45 orang $(33,6 \%)$. Selanjutnya tanggapan setuju sebanyak 49 orang $(36,6 \%)$, tanggapan kurang setuju sebanyak 30 orang $(22,4 \%)$ dan tanggapan tidak setuju sebanyak 10 orang $(7,5 \%)$. Dengan demikian mayoritas responden dalam penelitian ini menyatakan setuju bahwa Setiap karyawan mampu mengendalikan emosi dalam melaksanakan pekerjaannya agar tercipta suasana yang kondusif.

f. Pada Pernyataan keenam "Setiap karyawan memahami keadaan karyawan lain" mendapatkan tanggapan responden sangat setuju sebanyak 42 orang $(31,3 \%)$ dan tanggapan setuju sebanyak 77 orang (57.5\%), tanggapan kurang setuju sebanyak 14 orang $(10,4 \%)$ dan tanggapan tidak setuju sebanyak 1 orang $(0,7 \%)$. Dengan demikian mayoritas responden dalam penelitian ini menyatakan setuju bahwa Setiap karyawan memahami keadaan karyawan lain.
NIAGAWAN Vol 7 No 2 Juli 2018

g. Pada Pernyataan ketujuh "Setiap karyawan menghormati latar belakang budaya masing-masing" mendapatkan tanggapan responden sangat setuju sebanyak 47 orang $(35,1 \%)$. Selanjutnya tanggapan setuju sebanyak 80 orang $(59,7 \%)$ dan tanggapan kurang setuju sebanyak 7 orang $(5,2 \%)$. Dengan demikian mayoritas responden dalam penelitian ini menyatakan setuju bahwa Setiap karyawan menghormati latar belakang budaya masing-masing.

h. Pada Pernyataan ketujuh "Perusahaan tidak keberatan karyawan menggunakan bahasa daerah dalam berkomunikasi" mendapatkan tanggapan responden sangat setuju sebanyak 20 orang (14,9\%). Selanjutnya tanggapan setuju sebanyak 100 orang $(74,6 \%)$ dan tanggapan kurang setuju sebanyak 14 orang $(10,4 \%)$. Dengan demikian mayoritas responden dalam penelitian ini menyatakan setuju bahwa Perusahaan tidak keberatan karyawan menggunakan bahasa daerah dalam berkomunikasi.

Adapun tanggapan responden terhadap variabel kinerja karyawan dapat dilihat pada tabel 2 berikut ini:

Tabel 2

Tanggapan Responden Pada Variabel Kinerja Karyawan

\begin{tabular}{|c|c|c|c|c|c|c|c|c|c|c|}
\hline \multirow{2}{*}{ No } & \multicolumn{9}{|c|}{ Tanggapan Responden } \\
\cline { 2 - 12 } & \multicolumn{2}{|c|}{ SS } & \multicolumn{2}{|c|}{ S } & \multicolumn{2}{c|}{ KS } & \multicolumn{2}{|c|}{ TS } & \multicolumn{2}{c|}{ STS } \\
\cline { 2 - 12 } & F & $\%$ & F & $\%$ & F & $\%$ & F & $\%$ & F & $\%$ \\
\hline 1 & 44 & 32,8 & 83 & 61,9 & 7 & 5,2 & 0 & 0,0 & 0 & 0,0 \\
\hline 2 & 38 & 28,4 & 79 & 59,0 & 16 & 11,9 & 1 & 0,7 & 0 & 0,0 \\
\hline 3 & 42 & 31,3 & 81 & 60,4 & 11 & 8,2 & 0 & 0,0 & 0 & 0,0 \\
\hline 4 & 40 & 29,9 & 78 & 58,2 & 16 & 11,9 & 0 & 0,0 & 0 & 0,0 \\
\hline 5 & 44 & 32,8 & 76 & 56,7 & 14 & 10,4 & 0 & 0,0 & 0 & 0,0 \\
\hline
\end{tabular}


NIAGAWAN Vol 7 No 2 Juli 2018

\begin{tabular}{|c|c|c|c|c|c|c|c|c|c|c|}
\hline \multirow{2}{*}{ No } & \multicolumn{10}{|c|}{ Tanggapan Responden } \\
\cline { 2 - 13 } & \multicolumn{2}{|c|}{ SS } & \multicolumn{2}{|c|}{ S } & \multicolumn{2}{|c|}{ KS } & \multicolumn{2}{|c|}{ TS } & \multicolumn{2}{c|}{ STS } \\
\cline { 2 - 12 } & $\mathrm{F}$ & $\%$ & $\mathrm{~F}$ & $\%$ & $\mathrm{~F}$ & $\%$ & $\mathrm{~F}$ & $\%$ & $\mathrm{~F}$ & $\%$ \\
\hline 6 & 70 & 52,2 & 61 & 45,5 & 3 & 2,2 & 0 & 0,0 & 0 & 0,0 \\
\hline 7 & 45 & 33,6 & 65 & 48,5 & 24 & 17,9 & 0 & 0,0 & 0 & 0,0 \\
\hline 8 & 39 & 29,1 & 84 & 62,7 & 11 & 8,2 & 0 & 0,0 & 0 & 0,0 \\
\hline 9 & 35 & 26,1 & 93 & 69,4 & 6 & 4,5 & 0 & 0,0 & 0 & 0,0 \\
\hline 10 & 71 & 53,0 & 35 & 26,1 & 22 & 16,4 & 6 & 4,5 & 0 & 0,0 \\
\hline 11 & 40 & 29,9 & 69 & 51,1 & 25 & 18,7 & 0 & 0,0 & 0 & 0,0 \\
\hline 12 & 72 & 53,7 & 49 & 36,6 & 13 & 9,7 & 0 & 0,0 & 0 & 0,0 \\
\hline
\end{tabular}

Sumber: Hasil Penelitian, diolah (2018)

a. Pada pernyataan pertama "Saya menyelesaikan pekerjaan sesuai dengan target yang ditentukan perusahaan" diperoleh tanggapan sangat setuju sebnayak 44 orang $(32,8 \%)$. Selanjutnya tanggapan setuju sebesar 83 orang $(61,9 \%)$ dan tanggapan kurang setuju sebesar 7 orang $(5,2 \%)$. Dengan demikian mayoritas responden dalam penelitian ini menyatakan setuju bahwa Saya menyelesaikan pekerjaan sesuai dengan target yang ditentukan perusahaan

b. Pada Pernyataan kedua "Saya mampu menyelesaikan pekerjaan yang lebih banyak dari biasanya." mendapatkan tanggapan responden sangat setuju sebanyak 38 orang $(28,4 \%)$ serta tanggapan setuju sebanyak 79 orang $(59,0 \%)$. Selanjutnya tanggapan kurang setuju sebanyak 16 orang $(11,9 \%)$ dan tanggapan tidak setuju sebanyak 1 orang $(0,7 \%)$. Dengan demikian mayoritas responden dalam penelitian ini menyatakan setuju bahwa Saya mampu menyelesaikan pekerjaan yang lebih banyak dari biasanya.

c. Pada pernyataan ketiga "Saya berusaha menyelesaikan pekerjaan dengan upaya yang terbaik", diperoleh tanggapan sangat setuju sebnayak 42 orang $(31,3 \%)$. Selanjutnya tanggapan setuju sebesar 81 orang $(60,4 \%)$ dan tanggapan kurang setuju sebesar 11 orang $(8,2 \%)$. Dengan demikian mayoritas responden dalam penelitian ini menyatakan setuju bahwa Saya berusaha menyelesaikan pekerjaan dengan upaya yang terbaik.

d. Pada pernyataan keempat "Saya menyelesaikan setiap pekerjaan dengan teliti" mendapatkan tanggapan responden sangat setuju sebanyak 40 orang $(29,9 \%)$ serta tanggapan setuju sebanyak 78 orang $(58,2 \%)$. Sedangkan 16 responden menyatakan kurang setuju (11,9\%). Dengan demikian mayoritas responden dalam penelitian ini menyatakan setuju bahwa Saya menyelesaikan setiap pekerjaan dengan teliti

e. Pada pernyataan kelima "Saya selalu bekerja tepat waktu", diperoleh tanggapan sangat setuju sebnayak 44 orang $(32,8 \%)$. Selanjutnya tanggapan setuju sebesar 76 orang $(56,7 \%)$ dan tanggapan kurang setuju sebesar 14 orang (10,4\%). Dengan demikian mayoritas responden dalam penelitian ini menyatakan setuju bahwa Saya selalu bekerja tepat waktu.

f. Pada pernyataan keenam "Saya tidak pernah terlambat masuk kerja", diperoleh tanggapan sangat setuju 
NIAGAWAN Vol 7 No 2 Juli 2018

sebanyak 70 orang $(52,2 \%)$. Selanjutnya tanggapan setuju sebesar 61 orang $(45,5 \%)$ dan tanggapan kurang setuju sebesar 3 orang $(2,2 \%)$. Dengan demikian mayoritas responden dalam penelitian ini menyatakan sangat setuju bahwa Saya tidak pernah terlambat masuk kerja.

g. Pada pernyataan ketujuh "Saya melakukan pekerjaan dengan efektif dan jarang melakukan kesalahan." mendapatkan tanggapan responden sangat setuju sebanyak 45 orang $(33,6 \%)$ serta tanggapan setuju sebanyak 65 orang $(48,5 \%)$. Sedangkan 24 responden $(17,9 \%)$ menyatakan kurang setuju. Dengan demikian mayoritas responden dalam penelitian ini menyatakan setuju bahwa Saya melakukan pekerjaan dengan efektif dan jarang melakukan kesalahan.

h. Pada pernyataan kedelapan "Saya memiliki keterampilan untuk menyelesaikan pekerjaan dengan efektif." mendapatkan tanggapan responden sangat setuju sebanyak 39 orang $(29,1 \%)$ serta tanggapan setuju sebanyak 84 orang $(62,7 \%)$. Sedangkan 11 responden $(8,2 \%)$ menyatakan kurang setuju. Dengan demikian mayoritas responden dalam penelitian ini menyatakan setuju bahwa Saya memiliki keterampilan untuk menyelesaikan pekerjaan dengan efektif.

i. Pada pernyataan kesembilan "Saya mampu menyelesaikan pekerjaan baik sendiri maupun bersama tim." mendapatkan tanggapan responden sangat setuju sebanyak 35 orang $(26,1 \%)$ serta tanggapan setuju sebanyak 93 orang $(69,4 \%)$. Sedangkan 6 responden $(4,5 \%)$ menyatakan kurang setuju. Dengan demikian mayoritas responden dalam penelitian ini menyatakan setuju bahwa Saya mampu menyelesaikan pekerjaan baik sendiri maupun bersama tim.

j. Pada pernyataan kesepuluh "Saya mampu menyelesaikan tugas tanpa kesulitan" mendapatkan tanggapan responden sangat setuju sebanyak 71 orang $(53,0 \%)$ serta tanggapan setuju sebanyak 35 orang $(26,1 \%)$. Sedangkan 22 orang $(16,4 \%)$ menyatakan kurang setuju dan 6 orang $(4,5 \%)$ menyatakan tidak setuju. Dengan demikian mayoritas responden dalam penelitian ini menyatakan sangat setuju bahwa Saya mampu menyelesaikan tugas tanpa kesulitan.

k. Pada pernyataan kesebelas "Saya berkomitmen terhadap perusahaan mengenai tanggung jawab tugas dalam pekerjaan" mendapatkan tanggapan responden sangat setuju sebanyak 40 orang $(29,9 \%)$ serta tanggapan setuju sebanyak 69 orang $(51,5 \%)$. Sedangkan 25 responden $(18,7 \%)$ menyatakan kurang setuju. Dengan demikian mayoritas responden dalam penelitian ini menyatakan setuju bahwa Saya berkomitmen terhadap perusahaan mengenai tanggung jawab tugas dalam pekerjaan.

1. Pada pernyataan kesebelas "Saya berkomitmen untuk untuk menyelesaikan pekerjaan dengan optimal." mendapatkan tanggapan responden sangat setuju sebanyak 72 orang $(53,7 \%)$ serta tanggapan setuju sebanyak 49 orang $(36,6 \%)$. Sedangkan 13 responden $(9,7 \%)$ menyatakan kurang setuju. Dengan demikian mayoritas responden dalam penelitian ini menyatakan setuju bahwa Saya berkomitmen untuk untuk menyelesaikan pekerjaan dengan optimal. 
p-ISSN : 2301-7775

e-ISSN : 2579-8014

NIAGAWAN Vol 7 No 2 Juli 2018

\section{b. Uji Hipotesis}

Untuk mengetahui pengaruh human relation terhadap kinerja karyawan maka digunakan analisis regresi linear sederhaan

Tabel 3

berganda. Hasil analisis regresi linear sederhana dalam penelitian ini dapat dilihat pada tabel 3 dibawah ini:

Coefficients $^{\mathrm{a}}$

\begin{tabular}{|c|c|c|c|c|c|}
\hline \multirow{2}{*}{ Model } & \multicolumn{2}{|c|}{ Unstandardized Coefficients } & Standardized Coefficients & \multirow{2}{*}{$\mathrm{t}$} & \multirow{2}{*}{ Sig. } \\
\hline & B & Std. Error & Beta & & \\
\hline (Constant) & 2.687 & .281 & & 9.569 & .000 \\
\hline Human relation & .375 & .067 & .436 & 5.573 & .000 \\
\hline
\end{tabular}

a. Dependent Variable: kinerja karyawan 
. Hasil uji $\mathrm{t}$ dapat diketahui dengan melihat tabel 3. Pada tabel 3 diketahui nilai $t_{\text {hitung adalah }}$ sebesar 5,573 dan nilai $t$ tabel pada probabilitas 0,05 adalah sebesar 1,656 . Oleh karena itu $t_{\text {hitung }}$ $>\mathrm{t}_{\text {tabel }}(5,573>1,656)$ dan nilai $\mathrm{t}$ sig yaitu 0,000 $<0,05$. Dengan demikian dapat dinyatakan bahwa human relation berpengaruh positif dan signifikan terhadap kinerja karyawan PT. Perkebunan Timbang Langsa. Artinya hipotesis yang menyatakan human relation berpengaruh positif dan signifikan terhadap kinerja karyawan

Nilai koefisien determinasi $\left(\mathrm{R}^{2}\right)$ yaitu 0,19 Oatau 19,0\%. Hal ini menunjukkan variabel human relation mempengaruhi kinerja karyawan pada PT. Perkebunan Timbang Langsa sebesar $19,0 \%$, dan sisanya $81,0 \%$ dipengaruhi oleh variabel lain yang tidak diteliti dalam penelitian ini.

\section{KESIMPULAN DAN SARAN}

Kesimpulan dari penelitian ini adalah human relation berdampak positif dan signifkan terhadap kinerja sumberdaya manusia di dalam organisasi, dimana dalam penelitian ini dikalsanakan di PT Timbang Langsa. Meskipun demikian secara keseluruhan kontribusi human relation terhadap kinerja tidak besar ( $\mathrm{R}$ square 19\%) sehingga dari riset ini menunjukkan bahwa kinerja dipengaruhi faktor yang cukup kompleks.

\section{REFERENSI}

Asrifah. 2015. Pengaruh Human Relation terhadap Kinerja Pegawai di Kantor Wilayah Kementrian Agama Provinsi di Sulawesi Tengah. e-Jurnal Katalogis. Vol.3, No.2, Hal: 125-134

Bangun, Wilson, 2012, Manajemen Sumber Daya Manusia, Bandung: Erlangga.

Djaja, Danan. 2011. Peranan Humas Dalam Perusahaan. Jakarta: Graha Ilmu.

Davis, Keith. 2009. Perilaku dalam Organisasi. Jakarta: PT. Pustaka Binawan.

Effendy, Onong Uchjana. 2009. Human Relation dan Public Relation. Bandung: Mandar Maju.

Gibson, J.L dan Ivancevich, John M. 2010. Organisasi, Struktur dan Manajemen. ( Terjemahan: Djoerban Wahid, S.H ). Jakarta: Erlangga.

Hasibuan, Malayu S.P, 2009, Manajemen Sumber Daya Manusia, edisi revisi Jakarta: Bumi Aksara.
NIAGAWAN Vol 7 No 2 Juli 2018

Jalaludin, Rakhmat. 2011. Psikologi Komunikasi. Bandung: PT. Remaja Rosdakarya.

Kuncoro, Mudrajad. 2009. Metode Riset Untuk Bisnis dan Ekonomi. Jakarta, Erlangga.

Kurniati. 2009. Manajemen Sumber Daya Manusia. Jakarta: PT. Raja Grafindo Persada.

Kuswandi, Febriyanti, Rina dan Suryo Chayono. 2015. Pengaruh Human Relation, Iklim Organisasi dan Etos Kerja terhadap Kinerja Pegawai Dinas Pendidikan Kota BanjarBaru. Jurnal Ilmiah Ekonomi Bisnis. Vol.1, No.8, Hal:10-18.

Lungan, Richard. 2010. Aplikasi Statistika dan Hitung Peluang. Yogyakarta: Graha Ilmu.

Mahmudi. 2009. Manajemen Kinerja Sektor Publik. Yogyakarta: UPP AMP YKPN.

Mangkunegara, Anwar Prabu. 2011. Manajemen Sumber Daya Manusia Perusahaan. Bandung: PT. Remaja Rosdakarya.

Munasef. 2008. Manajemen Kepegawaian Indonesia. Jakarta: PT. Gunung Agung.

Rivai, V, Basri, A.F.M. 2012. Performance Appraisal. Jakarta: PT. Raja Grafindo Persada.

Rukmana, Widdi Ega. 2010. Analisis Pengaruh Human Relation (Hubungan Antar Manusia) Dan Kondisi Fisik Lingkungan Terhadap Etos Kerja Dan Kinerja Karyawan Dedy Jaya Plaza Tegal. Skripsi. Universitas Dipenogoro. Semarang.

Sedarmayanti. 2009. Manajemen Sumber Daya Manusia, Reformasi Birokrasi dan Manajemen Pegawai Negeri Sipil. Bandung: PT. Refika Aditama.

Siagian, Sondang P. 2012. Kiat Meningkatkan Produktivitas Kerja. Jakarta: PT Rineka Cipta.

Simamora, Henry. 2008. Manajemen Sumber Daya Manusia. Yogyakarta: STIE YKPN.

Simanjuntak, Payaman J. 2010. Manajemen dan Evaluasi Kinerja. Jakarta: FEUI

Sugiyono. 2014. Metode Penelitian Kuantitatif Kualitatif dan R\&D. Bandung: Alfabeta. 2011. Statistika Untuk Penelitian. Bandung: Alfabeta 2009. Metode Penelitian Kuantitatif,

Kualitatif dan R\&D. Bandung: Alfabeta.2014.

Susanti, Eka Cahyana Putri, Al Musadieq Mochammad dan Ika Ruhanna. Pengaruh Human Relation (Hubungan Antar Manusia dan Kondisi Lingkungan Kerja 
terhadap Kinerja Karyawan. Jurnal Administrasi Bisnis. Vol.17, No.2, Hal:19

Talumantak, Angreini, Kojo, Christoffel dan Lucky Dotulang. 2016. Analisis Pengaruh Human Relationship dan Beban Kerja terhadap Kinerja Pegawai pada Dinas Koperasi dan UMKM Provinsi Sulawesi Utara. Jurnal Berkala Ilmiah Efisiensi. Vol.16, No. 01, Hal:852-862

Umar, Husein, 2009, Manajemen Sumber Daya Manusia, Jakarta: Rineka Cipta.

Wibowo. 2012. Manajemen Kinerja. Jakarta: Rajawali Perss. 